\title{
Prevalence of folate deficiency among adolescent school girls in rural areas of Mysuru district, Karnataka, India
}

\author{
*K Jagadish Kumar ${ }^{1}$, V H Shravan Kumar ${ }^{1}$, Praveen Kulkarni ${ }^{2}$, K Jayashree ${ }^{3}$
}

Sri Lanka Journal of Child health, 2020; 49(3): 230-234

\begin{abstract}
Introduction: Adequate levels of folate are particularly important to adolescent girls and pregnant women. Inadequate maternal folic acid levels have been associated with placental abruption, pre-eclampsia, spontaneous abortion, stillbirth, prematurity, low birth weight and neural tube defects.
\end{abstract}

Objectives: To assess the prevalence of folate deficiency among adolescent school girls in rural areas of Mysuru District, Karnataka, India.

Method: This cross sectional, community based study was undertaken among 100 adolescent girls aged 14 to 16 years studying in four randomly selected rural schools of Mysuru district for a period of one year. Details regarding sociodemographic characteristics, dietary history and findings on clinical examination were recorded in a pre-tested structured schedule. Estimation of haemoglobin, mean corpuscular volume (MCV), mean corpuscular haemoglobin $(\mathrm{MCH})$, mean corpuscular haemoglobin concentration (MCHC) and serum folic acid levels was done along with peripheral blood pictures in all cases.

Results: Majority (66\%) of the girls were 15-16 years old. Prevalence of anaemia was $24 \%$ and prevalence of folic acid deficiency (serum folic acid $<2.7 \mathrm{ng} / \mathrm{ml}$ ) was $19 \%$. Around half (42.1\%) with folic acid deficiency had anaemia. Out of 19 girls with folic acid deficiency $16(84.2 \%)$ were vegetarians.

${ }^{1}$ Department of Paediatrics, ${ }^{2}$ Department of Community Medicine, ${ }^{3}$ Department of Pathology, JSS Medical College, JSS Academy of Higher Education and Research, Mysore, India *Correspondence: jagdishmandya@gmail.com

(iD)

orcid.org/ 0000-0001-9059-986X

(Received on 20 September 2019: Accepted after revision on 18 October 2019)

The authors declare that there are no conflicts of interest

Personal funding was used for the project.

Open Access Article published under the Creative

Commons Attribution CC-BY (c) (i)
Conclusions: In this study the prevalence of folate deficiency was 19\% among adolescent school girls in rural areas of Mysuru District, Karnataka, India.

http://dx.doi.org/10.4038/sljch.v49i3.9139

(Key words: Adolescent rural girls, folic acid, anaemia, vegetarian)

\section{Introduction}

Folate is naturally present in leafy vegetables, legumes, egg yolk, liver and citrus fruit ${ }^{1}$. Folate deficiency causes megaloblastic anaemia. When there is an increase in cell turnover, folic acid requirement increases ${ }^{1}$. Adolescence is a period of rapid growth requiring sufficient folate intake ${ }^{1}$. Adequate levels of folic acid are particularly important for adolescent females and pregnant women. Inadequate maternal folic acid levels have been associated with placental abruption, preeclampsia, spontaneous abortion, stillbirth, premature birth, low birth weight and neural tube defects (NTDs) ${ }^{1,2}$. World Health Organisation (WHO) recommends optimum serum and red cell folic acid levels in women of reproductive age, to prevent NTDs ${ }^{3}$. A meta-analysis of several Indian studies comprising 308,387 births detected NTDs in 4.1 per 1,000 births $^{4}$. Therefore attention should be paid to folate status in adolescent females. Folate fortification has increased serum and red cell folate levels in USA and Canada ${ }^{5}$. Data on folate levels in rural adolescent girls are however scanty.

\section{Objectives}

To assess the prevalence of folate deficiency among adolescent school girls in rural areas of Mysuru District, Karnataka, India.

\section{Method}

A cross sectional, community based study was carried out in rural schools of Mysuru district, India, which are under the field practice area of JSS Medical College, from 2017-2018, a period of 12 months. A total of 94 high schools in the rural area of Mysuru district were line listed and 4 schools randomly selected by lottery. Adolescent girls aged 14-16 years were included in study. The number of girls was selected by strength of particular high school by Probability Proportion to Size (PPS) sampling method. Sample size calculation, based on reported prevalence of folate deficiency of $52.5 \%$ with absolute allowable error of $10 \%, 95 \%$ 
confidence level and $80 \%$ power, was 99.8 , which was rounded to 100 . Girls who received blood transfusion in past 3 months and girls who received haematinics and multivitamins in the past 4-6 months were excluded from the study.

Institutional ethical committee clearance was obtained and informed consent was taken from the school authority and subjects. A detailed pro-forma with questions regarding the details was collected and a thorough examination was done. Weight and height of each adolescent girl was measured using a calibrated weight scale and stadiometer and body mass index (BMI) for age was calculated based on the CDC growth charts for children and teens (CDC, Atlanta, GA, USA). Estimation of serum folic acid level was done by electro chemiluminescence immunoassay "ECLIA" in fully automated hormone analyser Cobas E601E4 level. Haemoglobin, mean corpuscular volume (MCV), mean corpuscular haemoglobin (MCH) and mean corpuscular haemoglobin concentration (MCHC) levels were estimated by automated 6 part differential cell counter. Peripheral blood pictures were done by slide method using Leishman stain.

Statistical analysis: Data were entered into MS EXCEL and analysed utilising SPSS version 23. Inferential statistical tests like Chi-square test and Pearson correlation at ANOVA was applied.

\section{Results}

Of the 100 girls $66 \%$ were $15-16$ years old, $24 \%$ were anaemic and $66 \%$ were vegetarians. Majority $(93 \%)$ of the subjects had deficient calorie intake and $53 \%$ had adequate protein intake. According to the BMI 29\% were underweight (Table 1). Peripheral smear revealed normocytic normochromic picture in $87 \%$ of girls. Of the 100 girls, 19 (19\%) had folic acid deficiency (serum folic acid $<2.7 \mathrm{ng} / \mathrm{ml})$. Of the 19 with folic acid deficiency $8(42.1 \%)$ had anaemia and $16(84.2 \%)$ were vegetarians. The MCV was found to be higher $(85.968 \pm 10.095 \mathrm{fl})$ among subjects with folic acid deficiency compared to their normal counterparts $(81.091 \pm 7.993 \mathrm{fl})$ and this was statistically significant $(p=0.025)$ (Table 2$)$. Only 2 girls had MCV more than $100 \mathrm{fl}$.

Table 1

Demographic profile of adolescent rural girls

\begin{tabular}{|l|c|}
\multicolumn{2}{|c|}{ (n=100) } \\
\hline Age (years) & $n(\%)$ \\
14 to 15 & $34(34)$ \\
15 to 16 & $66(66)$ \\
\hline Anaemia status $(\mathrm{Hb}<12 \mathrm{~g} / \mathrm{dl})$ & \\
Anaemic & $24(24)$ \\
Non-anaemic & $76(76)$ \\
\hline Menarche & \\
Attained & $84(84)$ \\
Not attained & $16(16)$ \\
\hline Diet & \\
Vegetarian & $66(66)$ \\
Mixed & $34(34)$ \\
\hline Calorie intake & \\
Deficient & $93(93)$ \\
Adequate & $07(07)$ \\
\hline Protein intake & \\
Deficient & $47(47)$ \\
Adequate & $53(53)$ \\
\hline Body Mass Index (BMI) & $66(66)$ \\
Normal & $29(29)$ \\
Underweight & $04(04)$ \\
Overweight & $01(01)$ \\
Obese & \\
\hline
\end{tabular}

Table 2: Comparison of parameters with respect to serum folic acid levels

\begin{tabular}{|c|c|c|c|c|}
\hline \multirow[t]{2}{*}{ Parameter } & \multicolumn{2}{|c|}{ Folic acid level } & \multirow{2}{*}{$\begin{array}{c}\text { Total }(n=100) \\
\text { n }(\%)\end{array}$} & \multirow[t]{2}{*}{ p-value } \\
\hline & Deficient $(n=19)$ & Normal $(n=81)$ & & \\
\hline $\begin{array}{l}\text { Age (years) } \\
14 \text { to } 15 \mathrm{n}(\%) \\
15 \text { to } 16 \mathrm{n}(\%)\end{array}$ & $\begin{array}{l}04(11.8) \\
15(22.7) \\
\end{array}$ & $\begin{array}{l}30(88.2) \\
51(77.3) \\
\end{array}$ & $\begin{array}{l}34(34) \\
66(66) \\
\end{array}$ & 0.18 \\
\hline $\begin{array}{l}\text { Anaemia status }(\mathrm{Hb}<12 \mathrm{~g} / \mathrm{dl}) \\
\text { Anaemic } \\
\text { Non-anaemic }\end{array}$ & $\begin{array}{l}08(33.3) \\
11(14.5)\end{array}$ & $\begin{array}{l}16(66.7) \\
65(85.5)\end{array}$ & $\begin{array}{l}24(24) \\
76(76)\end{array}$ & 0.04 \\
\hline $\begin{array}{l}\text { Diet } \\
\text { Vegetarian } \\
\text { Mixed } \\
\end{array}$ & $\begin{array}{l}16(24.2) \\
03(08.8) \\
\end{array}$ & $\begin{array}{l}50(75.8) \\
31(91.2) \\
\end{array}$ & $\begin{array}{l}66(66) \\
34(34) \\
\end{array}$ & 0.063 \\
\hline $\begin{array}{l}\text { Calorie intake } \\
\text { Deficient } \\
\text { Adequate }\end{array}$ & $\begin{array}{l}15(16.1) \\
04(57.1) \\
\end{array}$ & $\begin{array}{l}78(83.9) \\
03(42.9) \\
\end{array}$ & $\begin{array}{l}93(93) \\
07(07)\end{array}$ & 0.008 \\
\hline $\begin{array}{l}\text { Blood Indices }(\text { Mean }+ \text { SD) } \\
\text { Haemoglobin }(\mathrm{g} / \mathrm{dl}) \\
\text { MCV }(\mathrm{fl}) \\
\mathrm{MCH}(\mathrm{pg}) \\
\mathrm{MCHC}(\mathrm{g} / \mathrm{dl}) \\
\end{array}$ & $\begin{array}{c}12.163 \pm 1.174 \\
85.968 \pm 10.09 \\
28.4 \pm 4.365 \\
32.915 \pm 1.549\end{array}$ & $\begin{array}{l}12.59 \pm 1.439 \\
81.091 \pm 7.99 \\
27.114 \pm 3.73 \\
33.318 \pm 1.78 \\
\end{array}$ & $\begin{array}{l}- \\
- \\
- \\
-\end{array}$ & $\begin{array}{l}0.232 \\
0.025 \\
0.194 \\
0.366 \\
\end{array}$ \\
\hline
\end{tabular}

MCV: Mean corpuscular volume, MCH: Mean corpuscular haemoglobin, MCHC: Mean corpuscular haemoglobin concentration 


\begin{abstract}
Discussion
Anaemia is highly prevalent in India and 60-90\% of adolescents suffer from anaemia ${ }^{6}$. Toteja et al reported anaemia in 90\% among 4337 adolescent girls in a study conducted in 16 districts of 10 states in India ${ }^{7}$. National Family Health Survey-3 study revealed that $56 \%$ Indian adolescent girls were having anaemia ${ }^{8}$. We observed anaemia in $24 \%$ of our rural adolescent girls. Deficiencies of folic acid, iron and vitamin B12 are documented as the aetiology of nutritional anaemia ${ }^{6}$. Among the severely anaemic adolescents, megaloblastic anaemia was the commonest $(42.5 \%)$, irondeficiency being noted only in $15 \%$ cases $^{9}$. Folate is important for adolescent girls to prepare for future pregnancy and prevention of complications secondary to low maternal folate status.
\end{abstract}

Among 200 anaemic adolescents, iron, folic acid and vitamin B12 deficiency were present in 30.5\%, $79.5 \%$ and $50 \%$ respectively ${ }^{10}$. In a study from Delhi, $39.8 \%$ of all adolescents had folate deficiency and it was more in the low income group $^{6}$. Out of 283 pregnant women from Haryana state, $26 \%$ had low serum folate levels ${ }^{11}$. Kapil and Sareen reported folate deficiency in $30.7 \%$ of children aged 12 to 18 years ${ }^{12}$. A study by Jani et al revealed that $66.7 \%$ of Indian tribal girls, 16-17 years old, were deficient in red cell folate ${ }^{13}$.

Folate deficiency has also been documented in adolescent girls from other countries. A study from Sudan revealed that $96.8 \%$ of 187 adolescent school girls had anaemia and folate deficiency was observed in $69 \%$ of them ${ }^{14}$. A study from Senegal revealed that $54.8 \%$ women were folate deficient ${ }^{15}$. A study from Bangladesh reported folic acid deficiency in 25\% in 310 anaemic adolescent 14-18 year old girls ${ }^{16}$. Out of 945 Sri Lankan school children (12-16 years), 54.8\% were found to be anaemic. Among the anaemic children folate deficiency was present in $54.6 \%$ boys and $52.5 \%$ girls ${ }^{17}$. In another study from Sri Lanka, among adolescent girls $45 \cdot 1 \%$ had low serum folic acid concentrations $^{18}$. Out of 100 adolescents from Venezuela, anaemia was observed in $78 \%$ and iron, folic acid and vitamin B12 deficiencies were noted in $35 \%, 91 \%$ and $18 \%$ respectively ${ }^{19}$. A study from Turkey reported folic acid deficiency in $16.3 \%$ of adolescent girls and this was more in rural $(20.1 \%)$ when compared to urban girls $(14.7 \%)^{1}$. In our study, $19 \%$ rural adolescent girls had deficient folic acid levels, which is similar to the study from Turkey. The difference in prevalence of folate deficiency among various studies could be due to difference in the age group of subjects included or variation in the dietary intake of folic acid, socioeconomic status, infections or maybe food fortification practice in their country.
In a study by Vitolo et al from Brazil, out of 722 adolescents, $89 \%$ had a lower than recommended folate intake ${ }^{20}$. Among 200 Indian adolescents, folate intake was deficient in $62.5 \%$ with anaemia $^{10}$. Among 16 to 17 year old adolescents, girls were 3.8 times more likely have deficient red cell folate than boys and folate intake was significantly lower in girls compared to boys ${ }^{13}$. Thoradeniya et al also observed that insufficient dietary intake of folate-rich foods was thought to be the main cause of folate deficiency ${ }^{18}$. In a study from Turkey, rural adolescent girls consumed less folic acid than their urban counterparts ${ }^{1}$.

Folate intake of tribal Indian adolescents was lower than the recommended dietary allowance ${ }^{13}$. However, $60 \%$ adolescents who were folate deficient had no anaemia ${ }^{13}$. In our study also there was no relationship between anaemia and folate status and only 2 had MCV more than $100 \mathrm{fl}$. Hence adolescents without anaemia could still be folate deficient ${ }^{13}$. Fortification programme in the USA led to an increase in red blood cell folate status by $33 \%$ and folic acid intake by $25 \%{ }^{13}$. In a study by Choudhary S, et al, out of 270 rural adolescent girls $68.5 \%$ were undernourished ${ }^{21}$. Even we observed that $29 \%$ of our rural adolescent girls were underweight. Green leafy vegetables and citrus fruits are important natural sources of folate in Indian diets ${ }^{13}$. In our study, $66 \%$ were vegetarians. Folic acid deficiency was $84 \%$ in vegetarians compared to $16 \%$ in those who had a mixed diet and this was statistically significant. Verma et al observed that $66 \%$ of vegetarians were anaemic compared to $38 \%$ of non-vegetarians ${ }^{22}$.

In the present study, 93\% of the adolescent girls had deficient calorie intake, of which $16 \%$ had folate deficiency which is statistically significant. Among the subjects with folic acid deficiency, 79\% had deficient calorie intake. Similar observations were made among adolescent girls from Turkey ${ }^{1}$.

Undernutrition, vegetarian diet, lower daily calorie intake and presence of nutritional anaemia were the factors commonly associated with folate deficiency. Thus there is a need to strengthen existing anaemia prevention and prophylaxis programmes and special emphasis should be paid to the behaviour change communication among the adolescent girls. The strategies for prevention of anaemia amongst adolescents in India should also include folate along with iron supplementation for prevention and control of nutritional anaemia.

\section{Conclusions}

In this study the prevalence of folate deficiency was $19 \%$ among adolescent school girls in rural areas of Mysuru District, Karnataka, India. 


\section{References}

1. Oner N, Vatansever U, Karasalihoğlu S, Ekuklu G, Celtik C, Biner B. The prevalence of folic acid deficiency among adolescent girls living in Edirne, Turkey. Journal of Adolescent Health 2006; 38: 599-606.

https://doi.org/10.1016/j.jadohealth.2005.0 3.027

PMid: 16635773

2. Molloy AM, Kirke PN, Brody LC, Scott JM, Mills JL. Effects of folate and vitamin B12 deficiencies during pregnancy on fetal, infant, and child development. Food and Nutrition Bulletin 2008; 29:S101-109. https://doi.org/10.1177/15648265080292S 114

PMid: 18709885

3. Cordero AM, Crider KS, Rogers LM, Cannon MJ, Berry RJ. Optimal serum and red blood cell folate concentrations in women of reproductive age for prevention of neural tube defects: World Health Organization guidelines. Morbidity and Mortality Weekly Report 2015; 64:421-3.

4. Bhide P, Sagoo GS, Moorthie S, Burton H, Kar A. Systematic review of birth prevalence of neural tube defects in India. Birth Defects Research (Part A) 2013; 97:437-43.

https://doi.org/10.1002/bdra.23153

PMid: 23873811

5. Pfeiffer CM, Caudill SP, Gunter EW, Osterloh J, Sampson EJ. Biochemical indicators of B vitamin status in the US population after folic acid fortification: results from the National Health and Nutrition Examination Survey 19992000. American Journal of Clinical Nutrition 2005; 82:442-50.

https://doi.org/10.1093/ajcn/82.2.442

PMid: 16087991

6. Kapil U, Bhadoria AS. Prevalence of folate, ferritin and cobalamin deficiencies amongst adolescents in India. Journal of Family Medicine and Primary Care 2014; 3(3):247-9.

https://doi.org/10.4103/2249-4863.141619

PMid: 25374863 PMCid: PMC4209681

7. Toteja GS, Singh P, Dhillon BS, Saxena BN, Ahmed FU, Singh RP, et al.
Prevalence of anaemia among pregnant women and adolescent girls in 16 districts of India. Food and Nutrition Bulletin 2006; 27: 311-5.

https://doi.org/10.1177/156482650602700

405

PMid: 17209473

8. Goyal N, Rawat C, Jha S. Prevalence of anaemia among school adolescent girls. Indian Journal of Community Health 2015; 27:398-401.

9. Patra S, Pemde HK, Singh V, Chandra J, Dutta A. Profile of adolescents with severe anaemia admitted in a tertiary care hospital in northern India. Indian Journal of Pediatrics 2011; 78:863-5. https://doi.org/10.1007/s12098-010-03362

PMid: 21222054

10. Thomas D, Chandra J, Sharma S, Jain A, Pemde HK. Determinants of nutritional anaemia in adolescents. Indian Pediatrics 2015; 52: 867-9. https://doi.org/10.1007/s13312-015-07347

PMid: 26499011

11. Pathak P, Kapil U, Kapoor SK, Saxena R, Kumar A, Gupta N, et al. Prevalence of multiple micronutrient deficiencies amongst pregnant women in a rural area of Haryana. Indian Journal of Pediatrics 2004; 71:1007-14. https://doi.org/10.1007/BF02828117 PMid: 15572822

12. Kapil U, Sareen N. Prevalence of ferritin, folate and vitamin B12 deficiencies amongst children in 5-18 years of age in Delhi. Indian Journal of Pediatrics 2014; 81(3):312. https://doi.org/10.1007/s12098-013-1091y

PMid: 23783764

13. Jani R, Salian N, Udipi S, Ghugre P, Lohia N, Haas $\mathrm{J}$ et al. Folate status and intake of tribal Indian adolescents aged 10 to 17 years. Food and Nutrition Bulletin 2005; 36:14-23. https://doi.org/10.1177/156482651503600 102

PMid: 25898712 
14. Abdelrahim II, Mahgoub HM, Mohamed AA, Ali NI, Elbashir MI, Adam I. Anaemia, folate, zinc and copper deficiencies among adolescent schoolgirls in Eastern Sudan. Biological Trace Element Research 2009; 132:60-6. https://doi.org/10.1007/s12011-009-83977

PMid: 19430735

15. Ndiaye NF, Idohou-Dossou N, Diouf A, Guiro AT, Wade S. Folate deficiency and anaemia among women of reproductive age (15-49 years) in Senegal: Results of a national cross-sectional survey. Food and Nutrition Bulletin 2018; 39:65-74.

https://doi.org/10.1177/037957211773906 3

PMid: 29129112

16. Ahmed F, Khan MR, Banu CP, Qazi MR, Akhtaruzzaman M. The coexistence of other micronutrient deficiencies in anaemic adolescent schoolgirls in rural Bangladesh. European Journal of Clinical Nutrition 2008; 62:365-72.

https://doi.org/10.1038/sj.ejcn.1602697

PMid: 17327866

17. Hettiarachchi

M, Liyanage C, Wickremasinghe R, Hilmers DC, Abrahams SA. Prevalence and severity of micronutrient deficiency: a cross-sectional study among adolescents in Sri Lanka. Asia Pacific Journal of Clinical Nutrition 2006; 15:56-63.
18. Thoradeniya $\mathrm{T}$, Wickremasinghe $\mathrm{R}$, Ramanayake R, Atukorala S. Low folic acid status and its association with anaemia in urban adolescent girls and women of childbearing age in Sri Lanka. British Journal of Nutrition 2006; 95:5116.

https://doi.org/10.1079/BJN20051590

PMid: 16512937

19. Suárez T, Torrealba M, Villegas $\mathrm{N}$, Osorio C, García-Casal MN. Iron, folic acid and vitamin B12 deficiencies related to anaemia in adolescents from a region with a high incidence of congenital malformations in Venezuela. Arch Latinoam Nutr. 2005; 55:118-23.

20. Vitolo MR, Canal Q, Campagnolo PDP, Gama CM. Factors associated with risk of low folate intake among adolescents. Journal of Pediatrics (Rio J.) 2006; 82: 2. https://doi.org/10.2223/JPED.1449 PMid: 16614766

21. Choudhary S, Mishra CP, Shukla KP. Nutritional status of adolescent girls in rural area of Varanasi. Indian Journal of Preventive and Social Medicine 2003; 34:54-61.

22. Verma M, Chhatwal J, Kaur G. Prevalence of anaemia among urban school children of Punjab, Indian Pediatrics 1999; 36:1181-6. 